\title{
Toxoplasma gondii and Neospora caninum in farm-reared ostriches (Struthio camelus) in China
}

\author{
Yongjie Feng ${ }^{1}$, Yaoyao Lu', Yinghua Wang ${ }^{2}$, Longxian Zhang ${ }^{1}$ and Yurong Yang ${ }^{1 *}$ (D)
}

\begin{abstract}
Background: The parasites Toxoplasma gondii (T. gondii) and Neospora caninum (N. caninum) are globally distributed; they infect warm-blooded animals, including many avian species. The aim of this study was to evaluate the presence of these parasites in ostriches from central China. In total, 402 ostrich (Struthio camelus) samples (293 hearts, 77 brains, and 32 serum) from slaughterhouses of the Henan Province and Hebei Province were collected. The heart juice $(n=283)$ and serum samples $(n=32)$ were tested for antibodies to T. gondii using the modified agglutination test (MAT). Hematoxylin and eosin (H\&E) staining, immunohistochemical (IHC) staining, and the polymerase chain reaction were used to examine the cysts and DNA of T. gondii and N. caninum parasites, respectively.
\end{abstract}

Results: Antibodies to T. gondii were detected in 6.4\% (20/315) (cut-off, 25). No cysts or DNA of T. gondii or N. caninum were observed in any of the 293 hearts and 77 brains.

Conclusion: The results showed a low prevalence of $T$. gondii antibody in ostriches, compared to that in the other animals. N. caninum occurs at low to negligible frequencies in ostriches from China. This is the first report on screening ostriches in China for T. gondii antibodies.

Keywords: Antibody, Cysts, DNA, Epidemiology, Modified agglutination test

\section{Background}

Toxoplasma gondii is an obligate cyst-forming parasite known to infect many species of warm-blooded animals, including ostrich $[1,2]$. Infection with $T$. gondii is usually asymptomatic, but it can cause severe illness in both humans and animals with weakened immune systems, and in the case of pregnancy [3]. Neospora caninum is a parasite similar to $T$. gondii in many respects as it causes abortion in cattle and paralysis in dogs $[4,5]$.

The breeding of ostriches for eggs, feathers, skin and meat is growing in China and its meat, in particular, is low in fat and highly palatable. The prevalence of $T$. gondii in free-range chickens is a good indicator of the presence of oocysts in the environment [6], and ostrich is much like free-range chickens that feed directly from

\footnotetext{
* Correspondence: yangyu7712@sina.com

'Laboratory of Veterinary Pathology, College of Animal Science and Veterinary Medicine, Henan Agricultural University, Zhengzhou 450002, People's Republic of China

Full list of author information is available at the end of the article
}

the ground. It was speculated that $T$. gondii and $N$. caninum infection in ostriches may assess the presence of oocysts in the local soil and environment. Furthermore, the consumption of undercooked ostrich meat containing $T$. gondii cysts might be a source of infection to consumers. Although the prevalence of T. gondii in ostriches has been reported in various countries [7-13], no research studies on $T$. gondii infection in ostriches from China have been conducted to date. Recently, the first report of isolation of $T$. gondii from ostriches was published [2]. The aim of this study was to determine the presence of $T$. gondii and $N$. caninum in farm-raised ostriches from China and attempt to isolate T. gondii.

\section{Methods \\ Sample collection}

A total of 402 ostrich (Struthio camelus) samples (283 fresh hearts, 77 fresh brains, 32 fresh sera, and 10 formalin-fixed hearts) from slaughterhouses in two provinces (Henan Province: 165 hearts, 77 brains, 32 sera and 10 formalin-fixed hearts samples; Hebei 
Province: 118 hearts) were collected between 2012 and 2015 (Table 1). All ostriches was above 10 months old, however the sex was unknown. The provinces of Henan $\left(31.38^{\circ}\right.$ to $36.37^{\circ} \mathrm{N}$ and $110.35^{\circ}$ to $\left.116.65^{\circ} \mathrm{E}\right)$ and Hebei $\left(36.08^{\circ}\right.$ to $42.67^{\circ} \mathrm{N}$ and $113.45^{\circ}$ to $119.83^{\circ} \mathrm{E}$ ) are located in central China. Unfrozen and fresh samples were transported to the Laboratory of Veterinary Pathology, Henan Agricultural University in cooler boxes. The ostriches were bred in paddocks and fed from the ground with greens and nutritious additives. Heart juice from 283 hearts was collected and centrifuged (1000 $g$, $5 \mathrm{~min}$ ) and then assayed for antibodies against $T$. gondii. A total of 315 samples (283 heart juice and 32 sera) were screened for $T$. gondii antibodies. The samples were kept in a refrigerator with a temperature range of $2{ }^{\circ} \mathrm{C}$ to $4{ }^{\circ} \mathrm{C}$ until analysis (within 1 week).

Screening of ostriches body fluids for $T$. gondii antibodies Using the modified agglutination test [14] at a dilution of 1:25, 1:50, 1:100 and 1:200, 315 body fluid samples (283 heart juice and 32 sera) were screened for $T$. gondii antibodies. T. gondii-positive serum from mice was used as a reference; negative serum and blank were performed in each plate. Whole formalin-treated T. gondii tachyzoite antigen was obtained from the Kerafast Company (Boston, MA, USA. Catalog No. EH2002). Serum dilution of 1:25 is effective for assessing the $T$. gondii antibody, which has been reported in ostriches and other animals $[7,8]$.

\section{Histopathological examination of ostrich heart and brain tissues for $T$. gondii and $N$. caninum}

A total of 370 ostrich tissue samples (293 hearts and 77 brains) were respectively cut into three pieces $(1.0 \times 1.0 \times 0.3 \mathrm{~cm})$, embedded in paraffin, and sectioned at a thickness of $5 \mu \mathrm{m}$. These tissue sections were then stained with hematoxylin and eosin $(\mathrm{H} \& \mathrm{E})$. Immunohistochemical (IHC) staining was used to verify suspected samples by rabbit polyclonal $T$. gondii antibody and mouse polyclonal $N$. caninum antibody. $T$. gondii-positive tissues or $N$. caninum-positive tissues from mice were used as reference; negative serum and blank were performed in each batch. The sections were examined with an Olympus CX21 optical microscope to search for cysts and determine the infection of $T$. gondii or N. caninum.

\section{Isolation of viable $T$. gondii from ostrich hearts by bioassay in mice}

Ostrich hearts that tested positive for $T$. gondii antibodies were bioassayed in mice individually $(n=8)$; sheep hearts containing T. gondii cysts were used as controls. Myocardia $(50 \mathrm{~g})$ from each heart were homogenized, digested in pepsin, and inoculated subcutaneously into 5 outbred Kunming mice, which were given water supplemented with dexamethasone phosphate $(10 \mu \mathrm{g} / \mathrm{ml}) \quad 3$ days before inoculation [3]. The remaining pepsin-digested myocardial samples were stored in $1.5 \mathrm{~mL}$ cryotubes at $-20{ }^{\circ} \mathrm{C}$ until further analysis. Clinical signs in these mice were observed daily. The mice were bled and sacrificed at 64 days post inoculation. Then the sera were diluted 1:25 and 1:200 to test for $T$. gondii antibodies; in addition, squash preparations of the brain were microscopically examined for $T$. gondii cysts. The mouse brains were then inoculated into new groups of mice.

\section{PCR identification of $T$. gondii and $N$. caninum in ostrich heart and brain tissues}

DNA was extracted from all tissue samples (293 hearts, 77 brains, and 8 pepsin -digested sediments of the myocardium) using a commercial DNA extraction kit (Tiangen Biotec Company, Beijing, China, DP304). PCR was used to detect the DNA of T. gondii (TOX5/TOX8) in amplified fragments of $450 \mathrm{bp}[15]$ and $N$. caninum (NP6/NP21) in fragments of 337 bp [16]. The DNA isolated from $T$. gondii (CT1 strain) or N. caninum (NC1 strain) was used as a reference for PCR.

\section{Statistical analysis}

Statistical analysis was performed using GraphPad Prism 4.0 (GraphPad Software Inc., San Diego, CA,

Table 1 Samples from Ostriches raised on farms in Henan Province and Hebei Province $(n=402)$

\begin{tabular}{|c|c|c|c|c|c|c|c|c|}
\hline \multirow[t]{2}{*}{ Location } & \multirow[t]{2}{*}{ Collection time } & \multirow[t]{2}{*}{ Samples No. } & \multicolumn{4}{|c|}{ Positive No. in different titers } & \multirow{2}{*}{$\begin{array}{l}\text { Total positive No. } \\
\text { and rate (\%) }\end{array}$} & \multirow{2}{*}{$\begin{array}{l}\text { Isolation obtained } \\
\text { by mice from samples }\end{array}$} \\
\hline & & & 25 & 50 & 100 & 200 & & \\
\hline Hebei Province & 2015 Summer/fall & 118 hearts & 0 & 0 & 0 & 0 & - & 0 \\
\hline \multirow[t]{3}{*}{ Henan Province } & 2015 Spring $^{\mathrm{b}}$ & 31 hearts & 1 & 0 & 0 & 0 & $1 / 31(3.2 \%)$ & $0 / 1$ \\
\hline & 2015 Fall $^{\mathrm{b}}$ & $\begin{array}{l}134 \text { hearts } \\
66 \text { brains } \\
32 \text { sera }\end{array}$ & $\begin{array}{l}13 \\
- \\
6\end{array}$ & $\begin{array}{l}10 \\
- \\
6\end{array}$ & $\begin{array}{l}8 \\
- \\
6\end{array}$ & 0 & 19/166 (11.5\%) & $0 / 7$ \\
\hline & $2012-2014$ & 10 hearts $^{c} 11$ brains $^{c}$ & - & & & & - & 0 \\
\hline Total & 2012-2015 & 293 hearts 77 brains 32 sera & 20 & 16 & 14 & 0 & $20 / 315(6.4 \%)$ & $0 / 8$ \\
\hline
\end{tabular}

${ }^{\mathrm{a}}$ Number of antibody-positive groups /Number of inoculated-groups

${ }^{\mathrm{b}} P$-value $>0.05$ by two-tailed chi-square tests for season factor in Henan Province

cformalin fixed samples 
USA). Data were analyzed by using the chi-square test or Fisher's exact test. $P<0.05$ was considered statistically significant.

\section{Results and discussion \\ T. gondii antibody testing}

$T$. gondii antibodies have been previously detected in the meat juice of pig, sheep, and cattle [17, 18]. In the present study, by using MAT, $T$. gondii antibodies were found in $6.4 \%(20 / 315)$ of the ostriches, with titers of 25 in 20, titers of 50 in 16, titers of 100 in 14 (8 hearts and 6 sera), and none showed a titer $>200$. The seroepidemiology of $T$. gondii was 10.2\% (20/197: 165 hearts, 32 sera) in Henan Province. None of the samples from Hebei Province (118 hearts) were positive (Table 1). Hebei is located north of Henan, drier and colder. The climate of Hebei Province may contribute to the negative toxoplasmosis results involving ostriches from the region. In Henan Province, 11.5\% (19/166) of the ostrich samples that were collected in the fall were seropositive for T. gondii, whereas 3.2\% (1/31) of those collected in the spring were seropositive. The risk of $T$. gondii infection in the fall was thus higher compared to that in the spring, with an odds ratio of 3.878 (95\% CI, 0.499530.10). However, this difference was not statistically significant $(P>0.05)$. This finding suggests that ostriches from Henan Province had been in contact with $T$. gondii oocysts from cats or from soil, water, or food. Ostriches feed from the ground, are raised much like free-range chickens and have a relatively free activity field. In Henan Province, the seroprevalence of $T$. gondii in freerange chickens was $18.9 \%(132 / 700)$ [19]; in cats, it was $52.3 \%(102 / 195)$ and $51.6 \%(16 / 31)[20,21] ; 12.7 \%(99 /$ $779)$ and $29.3 \%(83 / 283)$ in sheep [22, 23], 23.7\% (627/ 2642) in pig [24]. Compared with these reports, seroprevalence of $T$. gondii was lower among farm-reared ostriches $(10.2 \%, 20 / 197)$ in the same location. This result is consistent with other reports. A low prevalence of T. gondii antibodies in ostriches has been reported in other countries. The seroprevalence of $T$. gondii was about $74 \%$ to $80 \%$ among backyard chickens in Brazil $[25,26]$, but lower among ostriches (about $11 \%$ to $17 \%$ ) $[2,9,10]$ (Table 2). A summary of the prevalence of $T$. gondii in ostriches in various countries is shown in Table 2. Prevalence varies from $1 \%$ to $48 \%$, depending on the country. In conclusion, this is the first report to show the prevalence of $T$. gondii in ostriches from China.

\section{T. gondii isolation, T. gondii and N. caninum morphological and molecular assays}

Viable $T$. gondii had been isolated from ostrich brains, thereby serving as direct evidence that ostriches are intermediate hosts [2]. Isolation of T. gondii from the chicken heart or brain by bioassay in mice has been
Table 2 Prevalence of Toxoplasma gondii infection in ostriches

\begin{tabular}{lllll}
\hline Country & $\begin{array}{l}\text { No. of samples } \\
\text { received }\end{array}$ & $\begin{array}{l}\text { No. of seropositive } \\
(\%)\end{array}$ & $\begin{array}{l}\text { Serologic test } \\
\text { (cut-off titer) }\end{array}$ & References \\
\hline Zimbabwe & 50 & $24(48 \%)$ & MAT (25) & {$[8]$} \\
Canada & 973 & $28(3 \%)$ & MAT (25) & {$[7]$} \\
Brazil & 46 & $8(17 \%)$ & MAT (16) & {$[9]$} \\
& 195 & $28(14 \%)$ & MAT (16) & {$[10]$} \\
& 344 & $38(11 \%)$ & MAT (8) & {$[2]$} \\
Spain & 117 & $1(1 \%)$ & MAT (25) & {$[11]$} \\
Egypt & 120 & $15(13 \%)$ & MAT (25) & {$[12]$} \\
Iran & 28 & $6(21 \%)$ & ELISA & {$[13]$} \\
China & 315 & $20(6 \%)$ & MAT (25) & This study \\
\hline
\end{tabular}

shown to be effective [3, 27]. A previous study has shown that the density of $T$. gondii cysts in the heart is higher than that in muscle or brain of chickens [27]. Eight ostrich hearts were bioassayed in immunosuppressed Kunming mice in an effort to isolate T. gondii, but this was unsuccessful. Furthermore, H\&E or IHC staining did not detect any tissue cysts of $T$. gondii or $N$. caninum, and no positive DNA of $T$. gondii or $N$. caninum was detected by PCR in a total of 370 ostrich tissue samples and 8 pepsin-digested liquids from myocardia. These results may be explained by (1) the relative low density of $T$. gondii cysts in ostriches from China or (2) false positive on the MAT. Antigen from whole formalin-treated tachyzoites was used in the MAT. The MAT is highly sensitive and has been extensively used to test $T$. gondii antibodies in many animals and birds, including ostriches. The accuracy of the MAT has been validated in ostriches because 14/38 (36.8\%) isolation has been achieved [2]. However, we can not rule out the possibility that $T$. gondii antigen cross-reacts with other parasites (Hammondia hammondi) [28].

Some birds (chickens, pigeons, sparrows) have been shown to be intermediate hosts for $N$. caninum [29]. However, a recent literature search has found no study on $N$. caninum in ostriches. Ostriches have not been proven to be intermediate hosts for $N$. caninum. An examination of tissue sections was the most straightforward way of observing the parasites and lesions by light microscopy. Mineo found that no serological positivity of $N$. caninum was observed in 294 samples of serum. However, $N$. caninum cysts were found in Psittaciformes muscle by tissue section [30]. PCR is a sensitive method for detecting parasites. The DNA of $N$. caninum in the heart and brain of many animals has detected by PCR, particularly in the brains [31]. The absence of $N$. caninum from these ostrich samples suggests that this parasite occurs at low to negligible frequencies in ostriches from China. Further investigations using samples from different areas may facilitate in better understanding the process of neosporosis in ostriches. 


\section{Conclusions}

The results of the present study indicate that $T$. gondii has a lower prevalence in ostriches compared to other animals, the cause of this difference is unknown. However, consumers are precautions of eating raw or undercooked ostrich meat to avoid being infected with T. gondii. $N$. caninum occurs at low to negligible frequencies in ostriches from China. The establishment of differences in prevalence rates between ostrich and other birds may assist in the design of preventive and control measures against toxoplasmosis.

\section{Abbreviations}

H\&E: Hematoxylin and eosin staining; IHC: Immunohistochemistry; MAT: Modified agglutination test; PCR: Polymerase chain reaction

\section{Acknowledgments}

We thank J. P. Dubey (US Department of Agriculture, Beltsville, MD, USA) and J. Liu (China Agricultural University, Beijing, China) for providing positive serum, primary antibody, positive tissues, and DNA of T. gondii or N. caninum.

\section{Funding}

The China Henan Science and Technology Open and Cooperation Project (Grant No. 152106000056) and China Postdoctoral Science Foundation (Grant No. 2016M600577) supported this study.

\section{Availability of data and materials}

The data, materials, and protocols associated with this report may be shared by the readers without undue qualifications.

\section{Authors' contributions}

YJF performed the laboratory tests, data analysis, and wrote the manuscript. YYL, YHW participated in sample collection and laboratory testing. LXZ helped in the writing of the manuscript. YRY designed the study protocol, analyzed the results and helped in the writing of the manuscript. All authors have read and approved the final version of the manuscript.

\section{Ethics approval}

Ethical treatment of animals used in this study was approved by the Institutional Animal Use Committee of Henan Agricultural University (China). The protocol was approved by the Beijing Association for Science and Technology (SYXK [Beijing] 2007-0023).

\section{Consent for publication}

All authors consent for publication of this report.

\section{Competing interests}

The authors declare that they have no competing interests. None of the authors of this report have financial or personal relationships with other people or organizations that could inappropriately influence its content.

\section{Publisher's Note}

Springer Nature remains neutral with regard to jurisdictional claims in published maps and institutional affiliations.

\section{Author details}

${ }^{1}$ Laboratory of Veterinary Pathology, College of Animal Science and Veterinary Medicine, Henan Agricultural University, Zhengzhou 450002, People's Republic of China. ${ }^{2}$ Center for Animal Disease Control and Prevention of Henan Province, Zhengzhou 450002, People's Republic of China
Received: 28 June 2016 Accepted: 4 October 2017

Published online: 11 October 2017

\section{References}

1. Dubey JP. A review of toxoplasmosis in wild birds. Vet Parasitol. 2002; 106(2):121-53.

2. da Silva RC, Langoni H. Risk factors and molecular typing of Toxoplasma gondii isolated from ostriches (Struthio camelus) from a Brazilian slaughterhouse. Vet Parasitol. 2016;225:73-80.

3. Dubey JP. Toxoplasmosis of animals and humans. Boca Raton: CRC Press; 2010

4. Dubey JP. Neosporosis in dogs. Commonw Agric Bur Rev. 2013;8:1-26.

5. Lorenzi H, Khan A, Behnke MS, Namasivayam S, Swapna LS, Hadjithomas M, Karamycheva S, Pinney D, Brunk BP, Ajioka JW, Ajzenberg D, Boothroyd JC, Boyle JP, Dardé ML, Diaz-Miranda MA, Dubey JP, Fritz HM, Gennari SM, Gregory BD, Kim K, Saeij JP, Su C, White MW, Zhu XQ, Howe DK, Rosenthal BM, Grigg ME, Parkinson J, Liu L, Kissinger JC, Roos DS, Sibley LD. Local admixture of amplified and diversified secreted pathogenesis determinants shapes mosaic Toxoplasma gondii genomes. Nat Commun. 2016;7:10147.

6. Dubey JP. Toxoplasma gondii infections in chickens (Gallus domesticus): prevalence, clinical disease, diagnosis and public health significance. Zoonoses Public Health. 2010:57(1):60-73.

7. Dubey JP, Scandrett WB, OCH K, Gajadhar AA. Prevalence of antibodies to Toxoplasma gondii in ostriches (Struthio camelus). J Parasitol. 2000;86(3):623-4.

8. Hove T, Mukaratirwa S. Seroprevalence of Toxoplasma gondii in farm-reared ostriches and wild game species from Zimbabwe. Acta Trop. 2005:94(1):49-53.

9. Almeida AB, Krindges MM, de Barros LD, Garcia JL, Camillo G, Vogel FSF, Araujo DN, Stefani LM, da Silva AS. Occurrence of antibodies to Toxoplasma gondii in rheas (Rhea americana) and ostriches (Struthio camelus) from farms of different Brazilian regions. Rev Bras Parasitol Vet. 2013;22(3):437-9.

10. Contente APA, Domingues PF, da Silva RC. Prevalence of Toxoplasma gondii antibodies in ostriches (Struthio camelus) from commercial breeding facilities in the state of São Paulo, Brazil. Braz J Vet Res Anim Sci. 2009;46(3):175-80

11. Martínez-Díaz RA, Simmons B, Ponee-Gordo F. Serologic screening to detect Toxoplasma gondii antibodies in farmed ostriches (Struthio camelus) in Spain. Braz J Vet Parasitol. 2002;62(3-4):69-71.

12. El-Madawy SR, Metawea FY. Serological assays and PCR for detection of Toxoplasma gondii infection in an ostrich farm at Ismailia Provine. Egypt IOSR J Agr Vet Sci. 2013;2(3):56-60.

13. Rahimi E, Yazdanpour S, Dehkordi FS. Detection of Toxoplasma gondii antibodies in various poultry meat samples using enzyme linked immuno sorbent assay and its confirmation by polymerase chain reaction. J Pure Appl Microbio. 2014;8(1):421-7.

14. Dubey JP, Desmonts G. Serological responses of equids fed Toxoplasma gondii oocysts. Equine Vet J. 1987;19(4):337-9.

15. Su C, Dubey JP. Toxoplasma gondii in molecuar detection of foodborne pathogens. Boca Raton: CRC Press; 2009.

16. Liddell S, Jenkins MC, Dubey JP. A competitive PCR assay for quantitative detection of Neospora caninum. Int J Parasitol. 1999:29(10):1583-7.

17. Račka K, Bártová E, Budíková M, Vodrážka P. Survey of Toxoplasma gondii antibodies in meat juice of wild boar (Sus scrofa) in several districts of the Czech Republic. Ann Agric Environ Med. 2015;22(2):231-5.

18. Berger-Schoch AE, Bernet D, Doherr MG, Gottstein B, Frey CF. Toxoplasma gondii in Switzerland: a serosurvey based on meat juice analysis of slaughtered pigs, wild boar, sheep and cattle. Zoonoses Public Health. 2011;58(7):472-8

19. Feng YJ, Lu YY, Wang YH, Liu J, Zhang LX, Yang YR. Toxoplasma gondii and Neospora caninum in free-range chickens in Henan Province of China. Biomed Res Int. 2016;2016:8290536.

20. Wang HY, Pei SL, Hao ZF, Zhou M. Investigation on epidemiology of toxoplasmosis in dogs and cats in Zhengzhou City. J Henan Agr Sci. 2012; 41(11):153-4. In Chinese

21. Yang $Y R$, Ying $Y Q$, Verma SK, Cassinelli ABM, Kwok OCH, Liang HD, Pradhan AK, Zhu XQ, Su CL, Dubey JP. Isolation and genetic characterization of viable Toxoplasma gondii from tissues and feces of cats from the central region of China. Vet Parasitol. 2015:211(3-4):283-8.

22. Zhang N, Wang S, Wang D, Li CY, Zhang ZC, Yao ZJ, Li TT, Xie Q, Liu SG, Zhang HZ. Seroprevalence of Toxoplasma gondii infection and risk factors in domestic sheep in Henan Province, central China. Parasite. 2016;23:53. 
23. Yang YR, Feng YJ, Yao QX, Wang YH, Lu YY, Liang HD, Zhu XQ, Zhang LX. Seroprevalence, isolation, genotyping, and pathogenicity of Toxoplasma gondii strains from sheep in China. Front Microbiol. 2017;8:136.

24. Wen QN, Guo YH, Yang JF, Shen H, Du YC. Investigation on epidemiology of toxoplasmosis in pig from Henan Province. Chin J Vet Med. 2015;51(4): 44-5. In Chinese

25. Costa DGC, Marvulo MFV, Silva JSA, Santana SC, Magalhães FJR, Lima Filho CDF, Ribeiro VO, Alves LC, Mota RA, Dubey JP, Silva JCR. Seroprevalence of Toxoplasma gondii in domestic and wild animals from the Fernando de Noronha. Brazil J Parasitol. 2012;98(3):679-80.

26. Camillo G, Cadore GC, Ferreira MST, Braünig P, Maciel JF, Pivoto FL, Sangioni LA, Vogel FSF. Toxoplasma gondii and Neospora caninum antibodies in backyard chickens in Rio Grande do Sul. Brazil Braz J Poultry Sci. 2015;17(2):263-5.

27. Dubey JP, Lehmann T, Lautner F, Kwok OCH, Gamble HR. Toxoplasmosis in sentinel chickens (Gallus domesticus) in New England farms: seroconversion, distribution of tissue cysts in brain, heart, and skeletal muscle by bioassay in mice and cats. Vet Parasitol. 2015;214(1-2):55-8.

28. Munday BL, Dubey JP. Serological cross-reactivity between Hammondia hammondi and Toxoplasma gondii in experimentally inoculated sheep. Aust Vet J. 1986;63:344-5.

29. Donahoe SL, Lindsay SA, Krockenberger M, Phalen D, Šlapeta J. A review of neosporosis and pathologic findings of Neospora caninum infection in wildlife. Int J Parasitol Parasites Wildl. 2015:4(2):216-38.

30. Mineo TWP, Carrasco AOT, Raso TF, Werthera K, Pintoa AA, Machado RZ. Survey for natural Neospora caninum infection in wild and captive birds. Vet Parasitol. 2011;182(2-4):352-5.

31. Darwich L, Cabezon O, Echeverria I, Pabón M, Marco I, Molina-López R, Alarcia-Alejos O, López-Gatius F, Lavín S, Almería S. Presence of Toxoplasma gondii and Neospora caninum DNA in the brain of wild birds. Vet Parasitol. 2012;183(3-4):377-81.

\section{Submit your next manuscript to BioMed Central and we will help you at every step:}

- We accept pre-submission inquiries

- Our selector tool helps you to find the most relevant journal

- We provide round the clock customer support

- Convenient online submission

- Thorough peer review

- Inclusion in PubMed and all major indexing services

- Maximum visibility for your research

Submit your manuscript at www.biomedcentral.com/submit

) Biomed Central 